Sādhanā Vol. 39, Part 6, December 2014, pp. 1311-1331. (C) Indian Academy of Sciences

\title{
A comparative study on change vector analysis based change detection techniques
}

\author{
SARTAJVIR SINGH ${ }^{1, *}$ and RAJNEESH TALWAR ${ }^{2}$ \\ ${ }^{1}$ Department of Electronics Engineering, Punjab Technical University, \\ Kapurthala 144 601, India \\ ${ }^{2}$ Chandigarh Group of Colleges, College of Engineering, Landran \\ 140307, India \\ e-mail: sartajvir.dhillon@gmail.com; rtphdguidance@gmail.com
}

MS received 26 August 2013; revised 1 July 2014; accepted 11 July 2014

\begin{abstract}
Detection of Earth surface changes are essential to monitor regional climatic, snow avalanche hazard analysis and energy balance studies that occur due to air temperature irregularities. Geographic Information System (GIS) enables such research activities to be carried out through change detection analysis. From this viewpoint, different change detection algorithms have been developed for land-use land-cover (LULC) region. Among the different change detection algorithms, change vector analysis (CVA) has level headed capability of extracting maximum information in terms of overall magnitude of change and the direction of change between multispectral bands from multi-temporal satellite data sets. Since past two-three decades, many effective CVA based change detection techniques e.g., improved change vector analysis (ICVA), modified change vector analysis (MCVA) and change vector analysis posterior-probability space (CVAPS), have been developed to overcome the difficulty that exists in traditional change vector analysis (CVA). Moreover, many integrated techniques such as cross correlogram spectral matching (CCSM) based CVA. CVA uses enhanced principal component analysis (PCA) and inverse triangular (IT) function, hyper-spherical direction cosine (HSDC), and median CVA (m-CVA), as an effective LULC change detection tools. This paper comprises a comparative analysis on CVA based change detection techniques such as CVA, MCVA, ICVA and CVAPS. This paper also summarizes the necessary integrated CVA techniques along with their characteristics, features and shortcomings. Based on experiment outcomes, it has been evaluated that CVAPS technique has greater potential than other CVA techniques to evaluate the overall transformed information over three different MODerate resolution Imaging Spectroradiometer (MODIS) satellite data sets of different regions. Results of this study are expected to be potentially useful for more accurate analysis of LULC changes which will, in turn, improve the utilization of CVA based change detection techniques for such applications.
\end{abstract}

*For correspondence 
Keywords. Change vector analysis (CVA); improved change vector analysis (ICVA); modified change vector analysis (MCVA); change vector analysis posteriorprobability space (CVAPS).

\section{Introduction}

It has already been proven that remote sensing is only the practical means for detection of changes occurring over land-use land-cover (LULC) thousands of square kilometer area. Change detection analysis includes the use of multi-spectral bands of multi-temporal satellite data sets to discriminate the LULC changes (Gautam \& Chennaiah 1985). Lu et al (2003) represent different classes of change detection techniques such as algebraic techniques, transformation, classification, progressive techniques, geographical information system (GIS) techniques, visual analysis and other techniques. As compared to all change detection techniques, algebraic techniques such as band differencing (Weismiller et al 1977), ratioing (Howarth \& Wickware 1981), vegetation indices (Nelson 1983), regression analysis (Singh 1986), and change vector analysis (CVA) (Malila 1980), are easy to process. Among all algebraic techniques, change vector analysis (CVA) (Malila 1980) provides level headed capability of delivering spectral change information in terms of change-magnitude and change-direction (category) (Collins \& Woodcock 1994; Johnson \& Kasischke 1998; Houhoulis \& Michener 2000; Civco et al 2002; Allen \& Kupfer 2000; Hame et al 1998). Also, CVA has the capability of avoiding commission errors (including a pixel in a class when it should have been excluded) and Kappa coefficient (accuracy statistic that permits two or more contingency matrices to be compared) in retrieving maximum 'change and no-change' information.

Malila (1980) first implemented CVA for forest change detection which was implemented later on multi-spectral monitoring of coastal environment (Michalek et al 1993), high temporal dimensionality satellite data set (Lambin \& Strahler 1994), multi-spectral monitoring of land cover (Houhoulis \& Michener 2000), monitoring of selective logging activities (Silva et al 2003). Sohl (1999) discovered that CVA is the best among different change detection techniques because of its graphically rich content. Allen \& Kupfer (2000) developed an extended CVA technique using the information preserved in the vector's spherical statistics in the change extraction procedure but it contained some of its inherent drawbacks. Aiming to overcome the shortcomings in threshold value selection (Johnson \& Kasischke 1998; Smits \& Alessandro 2000; Ding et al 1998), a semi-automatic double-window flexible pace search (DFPS) threshold determination technique, has been proposed for LULC in improved change vector analysis (ICVA) (Chen et al 2003). ICVA also has the capability of decisive change-type information based on direction cosine (Hoffmann 1975) of change vectors. Modified change vector analysis (MCVA) (Nackaerts et al 2005) and change vector analysis in posterior probability space (CVAPS) (Chen et al 2011) techniques have been proposed to deliver output in continuous nature and to overcome radiometric errors, respectively.

Moreover, different integrated CVA techniques have also been designed to incorporate the features of other change detection techniques in CVA such as CVA by means of principal component analysis (PCA) and inverse triangular (IT) function (Baisantry et al 2012) for threshold selection, CVA uses tasseled cap (TC) to discriminate change in terms of brightness, greenness and wetness (Allen \& Kupfer 2000), cross correlogram spectral matching (CCSM) CVA (Chunyang et al 2013) to extract the degree of shape similarity between vegetation index (VI) profiles, and also CVA uses distance and similarity measures based on spectral angle mapper (SAM) and spectral correlation mapper (SCM) to the formulation of spectral direction change, and Euclidean distance to calculate magnitude (Osmar et al 2011), etc. Each CVA technique has 
its own capabilities and no one technique is suitable for every task (Johnson \& Kasischke 1998), so it is vital to evaluate a CVA technique on global basis that will constitute all the features.

In this paper, traditional CVA, MCVA, ICVA and CVAPS change detection techniques have been evaluated using three different MODIS satellite data sets. Apart from this, pre-processing of multi-temporal satellite dataset is a critical task because overall accuracy of each change detection technique depends upon the geometric correction, radiometric correction and atmospheric correction (Singh 1989; Markham \& Barker 1987; Gilabert et al 1994; Chavez 1996; Stefan \& Itten 1997; Vermote et al 1997; Tokola et al 1999; Yang \& Lo 2000; Mcgovern et al 2002; Mishra et al 2009a). The task of CVA based change detection technique will be initiated after all the necessary corrections, and selection of CVA technique depends on the required information, ground truth data availability, time and money constraints, knowledge and familiarity of the study area, complexity of landscape, and analyst's proficiency and experience (Lu et al 2003; Johnson \& Kasischke 1998). The aim of this paper is to investigate all the major CVA based change detection techniques.

This paper is organized in five sections. Following this introduction, a brief summary of essential pre-processing steps of satellite data is presented in section 2 . The comparative analysis of different CVA based change detection techniques are represented in third section, followed by results and discussion of prior studies along with their characteristics, features and limitations in fourth section. In section 5, general conclusion is provided.

\section{Pre-processing of satellite dataset}

In this paper, three different data sets from three different study areas have been acquired on $6^{\text {th }}$ November, 2010 and $8^{\text {th }}$ February, 2011 using MODIS (Moderate Resolution Imaging Spectroradiometer) sensor satellite over western Himalayan, India. First MODIS satellite dataset lies between $32.70^{\circ} \mathrm{N}$ to $33.05^{\circ} \mathrm{N}$ and $76.21^{\circ} \mathrm{E}$ to $76.92^{\circ} \mathrm{E}$ (figures $1 \mathrm{a}$ and b). Second MODIS satellite dataset lies between $32.70^{\circ} \mathrm{N}$ to $33.05^{\circ} \mathrm{N}$ and $76.57^{\circ} \mathrm{E}$ to $76.88^{\circ} \mathrm{E}$ (figures $1 \mathrm{c}$ and d). Third MODIS satellite dataset lies between $32.22^{\circ} \mathrm{N}$ to $32.57^{\circ} \mathrm{N}$ and $76.57^{\circ} \mathrm{E}$ to $76.88^{\circ} \mathrm{E}$ (figures $1 \mathrm{e}$ and f). Pre-processing of each satellite dataset is an important task for accurate analysis of change detection technique. Digital number (DN) or raw satellite imagery represents the energy reflected by Earth that depends on fraction of incoming solar radiation value, surface of slope and its orientation, surface anisotropy, and atmospheric constituents (Srinivasulu \& Kulkarni 2004). The approximation of spectral reflectance imagery includes different corrections such as geometric correction, radiometric correction, and topographic correction. The comprehensive study on satellite image interpretation can be referred to different studies (Singh 1989; Markham \& Barker 1987; Gilabert et al 1994; Chavez 1996; Stefan \& Itten 1997; Vermote et al 1997; Tokola et al 1999; Yang \& Lo 2000; Mcgovern et al 2002; Mishra et al 2009a). The radiometric correction converts the illumination values into reflectance values. The digital number (DN) imagery has transformed into reflectance ' $R$ ' imagery according to the following equation (Song et al 2001; Pandya et al 2002).

$$
R=\frac{\pi\left(L_{s a t \lambda}-L_{p}\right) d^{2}}{\left(E_{0} \cos \theta_{z}+E_{d}\right)},
$$

where ' $E_{0}^{\prime}$ and ' $L_{\text {sat } \lambda}^{\prime}$ represent the exo-atmospheric spectral irradiance and sensor radiance of MODIS (Mishra et al 2009b), respectively. The solar zenith angle is represented by ' $\theta_{z}^{\prime}$ which is calculated for all different pixels (Kasten 1989), ' $d$ ' represents the distance between Earth and Sun (Van 1989), ' $E_{d}^{\prime}$ is the down-welling diffused radiation which can be represented as 'zero' (Chavez 1984). The path radiance is represented by ' $L_{p}^{\prime}$ (Gilabert et al 1994). 


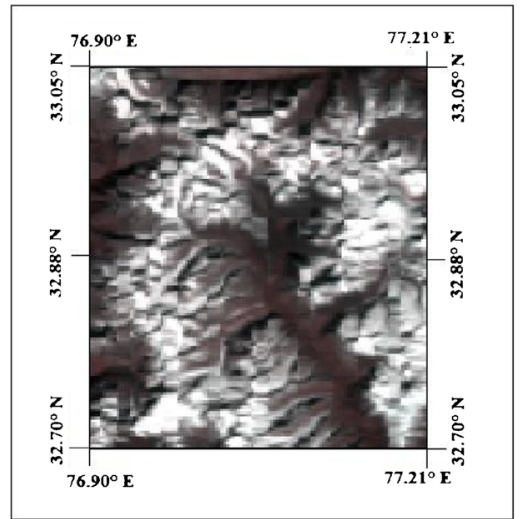

(a)

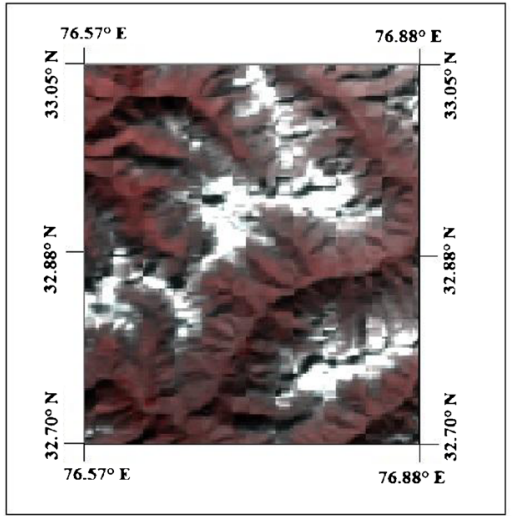

(c)

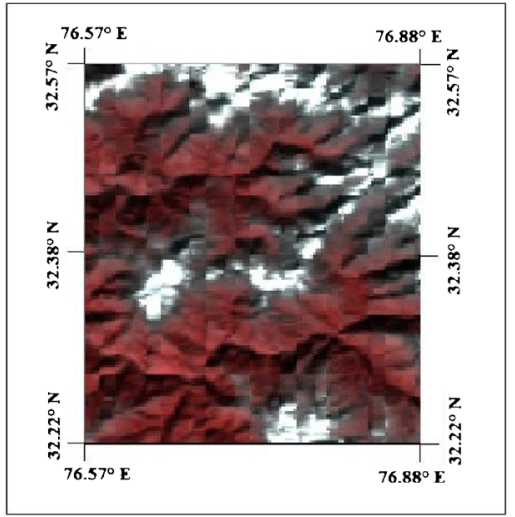

(e)

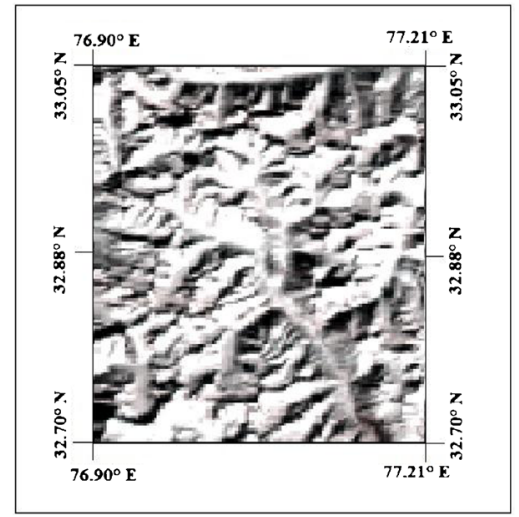

(b)

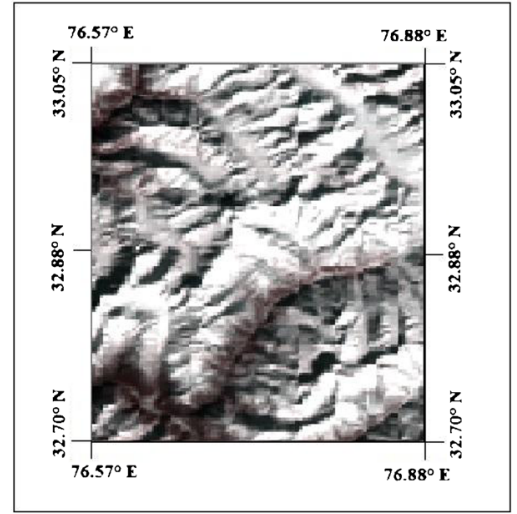

(d)

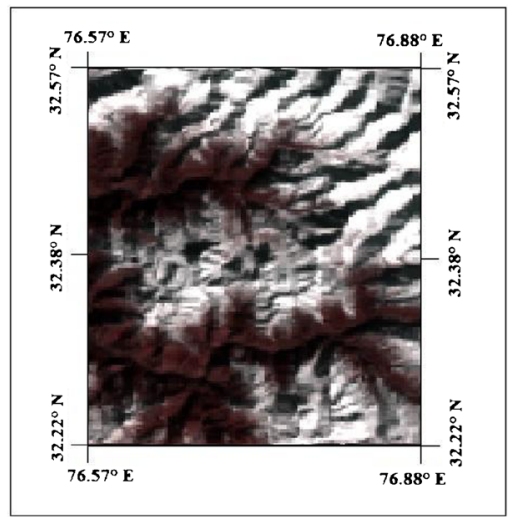

(f)

Figure 1. MODIS satellite datasets: (a) Pre-date $\left(6^{\text {th }}\right.$ November, 2010) imagery of dataset 1 , (b) Post-date $\left(8^{\text {th }}\right.$ February, 2011) imagery of dataset 1 , (c) Pre-date $\left(6^{\text {th }}\right.$ November, 2010$)$ imagery of dataset 2 , (d) Postdate $\left(8^{\text {th }}\right.$ February, 2011) imagery of dataset 2 , (e) Pre-date $\left(6^{\text {th }}\right.$ November, 2010) imagery of dataset 3 , (f) Post-date $\left(8^{\text {th }}\right.$ February, 2011) imagery of dataset 3. 


\section{Change vector analysis (CVA)}

Change vector analysis (CVA) is a change detection tool that characterizes dynamic changes in multi-spectral space by a change vector over multi-temporal imageries (Malila 1980). The basic concept of CVA is derived from image differencing technique (Lu et al 2003). The CVA can overcome the disadvantages of 'type-one' approaches e.g., cumulative errors in image classification of an individual date and processing any number of spectral bands simultaneously to retrieve maximum change-type information (Malila 1980). A number of CVA based change detection techniques have been developed to make change detection more accurate for identifying changed area. In this paper, we have implemented all major CVA based change detection techniques on three different data sets to investigate the accuracy of each technique on global basis. The comparative analysis of different CVA algorithms have been shown in figures 2 and 3 .

\subsection{Traditional change vector analysis (CVA)}

The concept of the traditional change vector analysis (CVA) involves the calculation of spectral change based on multi-temporal pairs of spectral measurements, and relate their magnitudes to a stated threshold criterion (Malila 1980). The computed change vectors comprise essential information in magnitude and direction (figure 2). The two important reasons that make CVA a more level headed change detection technique than other techniques are: (a) it relies on entirely contiguous pixels; (b) it relaxes the requirement of training and ground truth data. In figure 4, the change vector magnitude imageries for three different MODIS satellite data sets of different regions have been calculated according to following Equation (Malila 1980; Chen et al 2003) in which transformed data is represented by ' $\Delta \mathrm{H}^{\prime}$ that lies between the two multi-temporal imageries $\left(\mathrm{T}_{1}: 06^{\text {th }}\right.$ November 2010 and $\mathrm{T}_{2}: 08^{\text {th }}$ November 2011) captured for a given pixel defined by $\mathrm{Y}=\left(\mathrm{y}_{1}, \mathrm{y}_{2}, \ldots \mathrm{y}_{\mathrm{i}}\right)^{\mathrm{T}_{1}}$ and $\mathrm{X}=\left(\mathrm{x}_{1}, \mathrm{x}_{2}, \ldots \mathrm{x}_{1}\right)^{\mathrm{T}_{2}}$, respectively and ' $i$ ' represents number of bands in imagery.

$$
|\Delta \mathrm{H}|=\sqrt{\left(\mathrm{x}_{1}-\mathrm{y}_{1}\right)^{2}+\cdots+\left(\mathrm{x}_{\mathrm{i}}-\mathrm{y}_{\mathrm{i}}\right)^{2}} .
$$

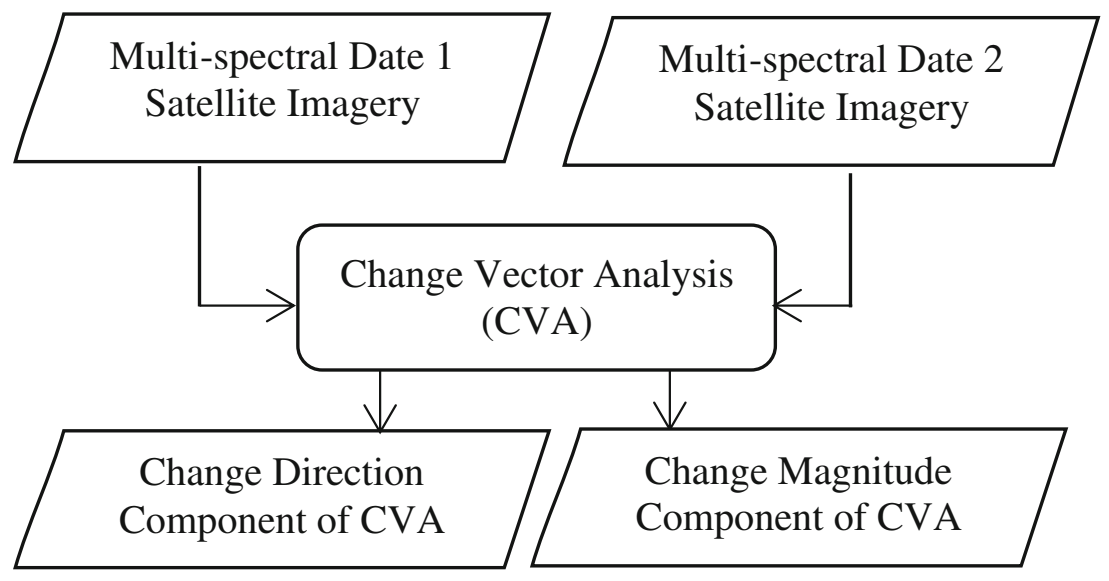

Figure 2. Basic algorithm of CVA in multi-dimensional space. 


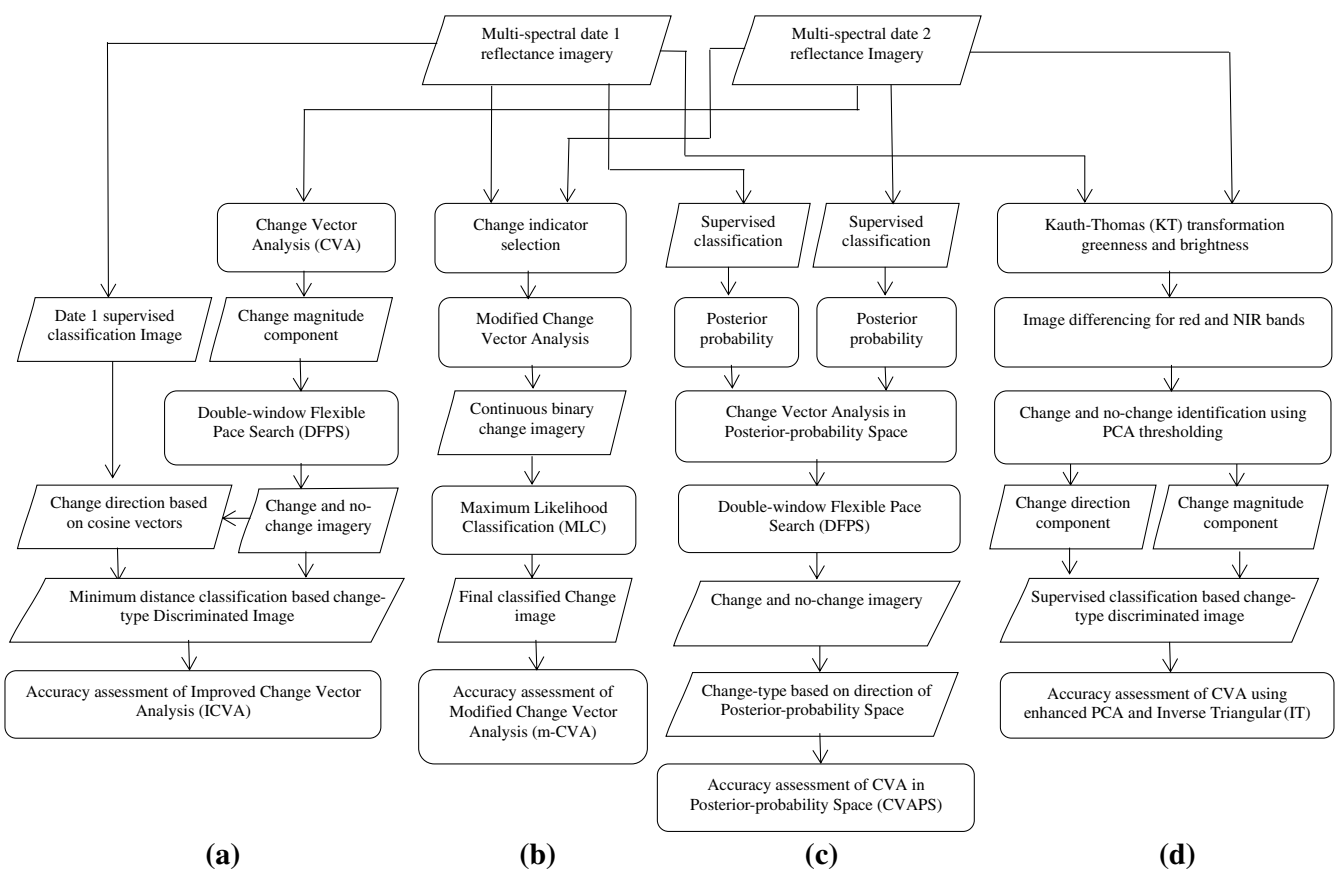

Figure 3. Comparative study on different Change Vector Analysis (CVA) based change detection algorithms: (a) ICVA, (b) m-CVA, (c) CVAPS, (d) CVA using PCA and IT.

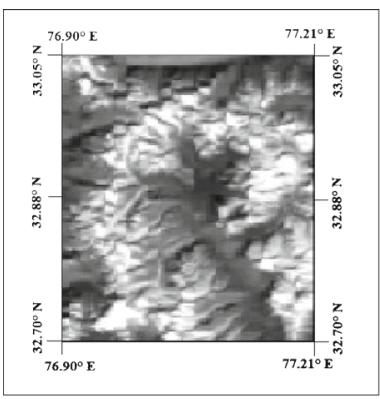

(a)

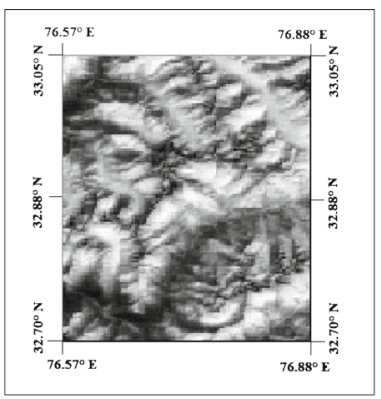

(b)

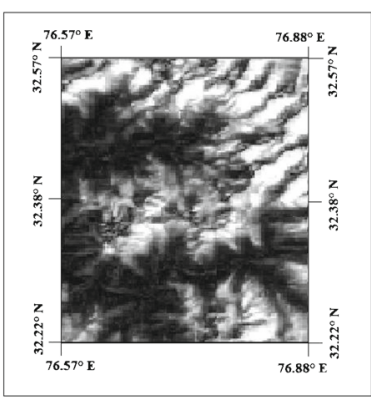

(c)

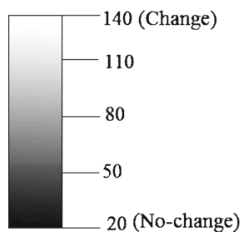

(d)

Figure 4. Change magnitude imageries: (a) Dataset 1, (b) Dataset 2, (c) Dataset 3 and, (d) Change magnitude 'change' and 'no-change' scale (140-20 represent maximum to minimum values of change magnitude imagery). 


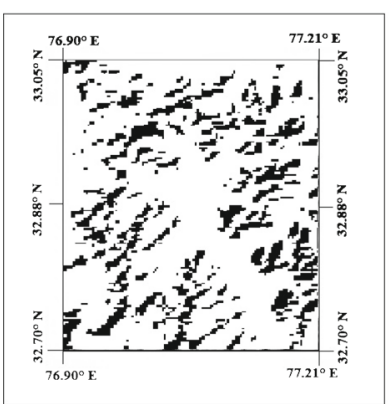

(a)

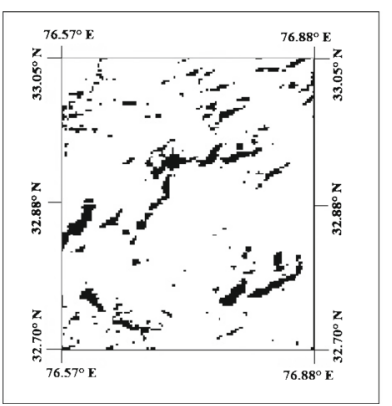

(b)

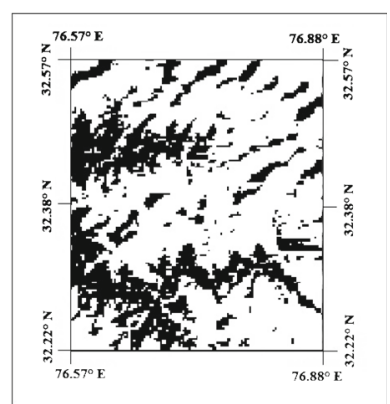

(c)

Figure 5. Binary imageries generated using CVA: (a) Dataset 1, (b) Dataset 2 and, (c) Dataset 3.

The main drawback of CVA technique is manual selection of threshold value to discriminate 'change' and 'no-change' pixels. In figure 5, binary image generated through CVA for three different data sets represented the 'change' pixels in white colour and 'no-change' pixels in black colour.

\subsection{Improved change vector analysis (ICVA)}

A semiautomatic threshold determination technique, called double-window flexible pace search (DFPS) has been proposed in improved change vector analysis (ICVA) (Chen et al 2003). The DFPS technique effectively determines the threshold value from change magnitude imagery (Allen \& Kupfer 2000) as shown in figure 3a. The succession rate criteria of DFPS has been used to evaluate the performance of each potential threshold value during one search process for identifying 'change' and 'no-change' pixels. In semi-automatic DFPS process, success rate $\left(S_{r}\right)$ criteria is calculated from training sample of three different respective satellite data sets (figure 6), according to the following equation to select the most optimal threshold value for change magnitude imagery.

$$
S r=\frac{\left(I_{c}-O_{c}\right)}{I_{t}} \% \text {. }
$$

In Eq. (3), ' $I_{c}^{\prime}$ represents number of transformed pixels inside an inner window sample, ${ }^{\prime} O_{c}^{\prime}$ represents number of transformed pixels in an outer window sample and ' $I_{t}^{\prime}$ is the total number of pixels in inner training window sample. Table 1 represents the results of succession rate for

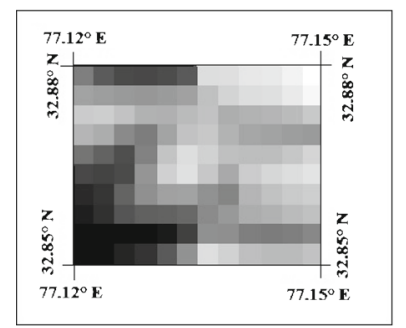

(a)

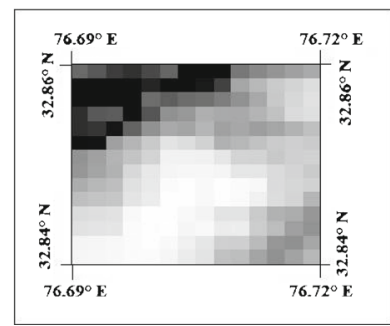

(b)

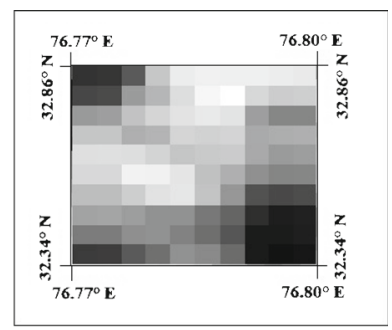

(c)

Figure 6. Training sample subset for threshold value selection: (a) Dataset 1, (b) Dataset 2 and, (c) Dataset 3 . 
Table 1. Succession rate results of DFPS threshold determination (ICVA) technique for dataset 1.

\begin{tabular}{|c|c|c|c|c|c|c|c|c|c|}
\hline \multicolumn{2}{|c|}{$\begin{array}{c}\text { Range }=30-150 \\
\text { Pace }=20\end{array}$} & \multicolumn{2}{|c|}{$\begin{array}{c}\text { Range }=40-70 \\
\text { Pace }=10\end{array}$} & \multicolumn{2}{|c|}{$\begin{array}{c}\text { Range }=50-70 \\
\text { Pace }=5\end{array}$} & \multicolumn{2}{|c|}{$\begin{array}{c}\text { Range }=60-70 \\
\text { Pace }=2-3\end{array}$} & \multicolumn{2}{|c|}{$\begin{array}{c}\text { Range }=62-68 \\
\text { Pace }=1\end{array}$} \\
\hline $\begin{array}{l}\text { Cut-off } \\
\text { value }\end{array}$ & $\begin{array}{c}\text { Success } \\
\text { percentage }\end{array}$ & $\begin{array}{l}\text { Cut-off } \\
\text { value }\end{array}$ & $\begin{array}{c}\text { Success } \\
\text { percentage }\end{array}$ & $\begin{array}{l}\text { Cut-off } \\
\text { value }\end{array}$ & $\begin{array}{c}\text { Success } \\
\text { percentage }\end{array}$ & $\begin{array}{l}\text { Cut-off } \\
\text { value }\end{array}$ & $\begin{array}{c}\text { Success } \\
\text { percentage }\end{array}$ & $\begin{array}{l}\text { Cut-off } \\
\text { value }\end{array}$ & $\begin{array}{c}\text { Success } \\
\text { percentage }\end{array}$ \\
\hline 30 & $50.00 \%$ & 40 & $50.00 \%$ & 50 & $51.25 \%$ & 60 & $51.25 \%$ & 62 & $52.50 \%$ \\
\hline 50 & $51.00 \%$ & 50 & $51.00 \%$ & 55 & $51.25 \%$ & 62 & $52.50 \%$ & 63 & $52.50 \%$ \\
\hline 70 & $48.75 \%$ & 60 & $51.25 \%$ & 60 & $51.25 \%$ & 65 & $53.75 \%$ & 64 & $52.50 \%$ \\
\hline 90 & $38.75 \%$ & 70 & $48.75 \%$ & 65 & $53.75 \%$ & 68 & $52.50 \%$ & 65 & $53.75 \%$ \\
\hline 110 & $16.07 \%$ & & & 70 & $48.75 \%$ & 70 & $48.75 \%$ & 66 & $52.50 \%$ \\
\hline 130 & $5.35 \%$ & & & & & & & 67 & $52.50 \%$ \\
\hline 150 & $5.35 \%$ & & & & & & & 68 & $48.75 \%$ \\
\hline
\end{tabular}

dataset 1, table 2 represents the results of succession rate for dataset 2, and table 3 represents the results of succession rate for dataset 3 . In figure 7, binary image generated through ICVA for three different data sets represented the 'change' pixels in white colour and 'no-change' pixels in black colour.

\subsection{Modified change vector analysis (MCVA)}

Additional development in change vector analysis, has been made by modified change vector analysis (MCVA) (Nackaerts et al 2005) technique which preserves the change information in the magnitude and direction of change vector as continuous data and provided the capability to execute ' $n$ ' change indicator input bands, simultaneously. The overall result of MCVA is a feature space where Cartesian coordinates in a continuous domain are used to describe each change vector. A significant advantage of this technique is that change classification is now entirely on the continuous data domain which permits change descriptors to be used in common change categorization methods. The MCVA technique is simple to execute as compared to ICVA (Chen et al 2003) as shown in figure 3b, because empirical technique has been used for the determination of threshold value instead of any semi/automatic procedure. The manual threshold determination technique depends on analyst's skill and effects the accuracy assessment. In

Table 2. Succession rate results of DFPS threshold determination (ICVA) technique for dataset 2.

\begin{tabular}{|c|c|c|c|c|c|c|c|c|c|}
\hline \multicolumn{2}{|c|}{$\begin{array}{c}\text { Range }=20-140 \\
\text { Pace }=20\end{array}$} & \multicolumn{2}{|c|}{$\begin{array}{c}\text { Range }=40-80 \\
\text { Pace }=10\end{array}$} & \multicolumn{2}{|c|}{$\begin{array}{c}\text { Range }=50-70 \\
\text { Pace }=5\end{array}$} & \multicolumn{2}{|c|}{$\begin{array}{c}\text { Range }=60-70 \\
\text { Pace }=2-3\end{array}$} & \multicolumn{2}{|c|}{$\begin{array}{c}\text { Range }=62-68 \\
\text { Pace }=1\end{array}$} \\
\hline $\begin{array}{l}\text { Cut-off } \\
\text { value }\end{array}$ & $\begin{array}{c}\text { Success } \\
\text { percentage }\end{array}$ & $\begin{array}{l}\text { Cut-off } \\
\text { value }\end{array}$ & $\begin{array}{c}\text { Success } \\
\text { percentage }\end{array}$ & $\begin{array}{l}\text { Cut-off } \\
\text { value }\end{array}$ & $\begin{array}{c}\text { Success } \\
\text { percentage }\end{array}$ & $\begin{array}{l}\text { Cut-off } \\
\text { value }\end{array}$ & $\begin{array}{c}\text { Success } \\
\text { percentage }\end{array}$ & $\begin{array}{l}\text { Cut-off } \\
\text { value }\end{array}$ & $\begin{array}{c}\text { Success } \\
\text { percentage }\end{array}$ \\
\hline 20 & $39.05 \%$ & 40 & $48.12 \%$ & 50 & $59.02 \%$ & 60 & $60.40 \%$ & 62 & $60.40 \%$ \\
\hline 40 & $48.12 \%$ & 50 & $59.02 \%$ & 55 & $59.02 \%$ & 62 & $60.40 \%$ & 63 & $60.40 \%$ \\
\hline 60 & $60.40 \%$ & 60 & $60.40 \%$ & 60 & $60.40 \%$ & 65 & $61.11 \%$ & 64 & $60.40 \%$ \\
\hline 80 & $57.63 \%$ & 70 & $59.02 \%$ & 65 & $61.11 \%$ & 68 & $59.02 \%$ & 65 & $61.11 \%$ \\
\hline 100 & $53.47 \%$ & 80 & $57.63 \%$ & 70 & $59.02 \%$ & 70 & $59.02 \%$ & 66 & $60.40 \%$ \\
\hline 120 & $39.58 \%$ & & & & & & & 67 & $59.02 \%$ \\
\hline 140 & $20.83 \%$ & & & & & & & 68 & $59.02 \%$ \\
\hline
\end{tabular}


Table 3. Succession rate results for DFPS threshold determination (ICVA) technique for dataset 3 .

\begin{tabular}{|c|c|c|c|c|c|c|c|c|c|}
\hline \multicolumn{2}{|c|}{$\begin{array}{c}\text { Range }=20-140 \\
\text { Pace }=20\end{array}$} & \multicolumn{2}{|c|}{$\begin{array}{c}\text { Range }=40-80 \\
\text { Pace }=10\end{array}$} & \multicolumn{2}{|c|}{$\begin{array}{c}\text { Range }=50-70 \\
\text { Pace }=5\end{array}$} & \multicolumn{2}{|c|}{$\begin{array}{c}\text { Range }=60-70 \\
\text { Pace }=2-3\end{array}$} & \multicolumn{2}{|c|}{$\begin{array}{c}\text { Range }=61-65 \\
\text { Pace }=1\end{array}$} \\
\hline $\begin{array}{l}\text { Cut-off } \\
\text { value }\end{array}$ & $\begin{array}{c}\text { Success } \\
\text { percentage }\end{array}$ & $\begin{array}{l}\text { Cut-off } \\
\text { value }\end{array}$ & $\begin{array}{c}\text { Success } \\
\text { percentage }\end{array}$ & $\begin{array}{l}\text { Cut-off } \\
\text { value }\end{array}$ & $\begin{array}{c}\text { Success } \\
\text { percentage }\end{array}$ & $\begin{array}{l}\text { Cut-off } \\
\text { value }\end{array}$ & $\begin{array}{c}\text { Success } \\
\text { percentage }\end{array}$ & $\begin{array}{l}\text { Cut-off } \\
\text { value }\end{array}$ & $\begin{array}{c}\text { Success } \\
\text { percentage }\end{array}$ \\
\hline 20 & $45.31 \%$ & 40 & $45.31 \%$ & 50 & $50.00 \%$ & 60 & $51.56 \%$ & 61 & $51.56 \%$ \\
\hline 40 & $45.31 \%$ & 50 & $50.00 \%$ & 55 & $50.00 \%$ & 62 & $52.56 \%$ & 62 & $52.56 \%$ \\
\hline 60 & $51.56 \%$ & 60 & $51.56 \%$ & 60 & $51.56 \%$ & 65 & $51.56 \%$ & 63 & $51.56 \%$ \\
\hline 80 & $48.43 \%$ & 70 & $51.55 \%$ & 65 & $51.56 \%$ & 68 & $51.56 \%$ & 64 & $51.56 \%$ \\
\hline 100 & $31.25 \%$ & 80 & $48.43 \%$ & 70 & $51.56 \%$ & 70 & $51.56 \%$ & 65 & $51.56 \%$ \\
\hline 120 & $15.62 \%$ & & & & & & & & \\
\hline 140 & $10.30 \%$ & & & & & & & & \\
\hline
\end{tabular}

figure 8 binary image generated through MCVA for three different data sets represented the 'change' pixels in white colour and 'no-change' pixels in black colour.

\subsection{Change vector analysis in posterior probability space (CVAPS)}

All CVA based change detection techniques necessitate a consistent radiometric imagery because CVA is based on pixel-wise radiometric resolution. The requirement of reliable radiometric for image processing limits the application of CVA (Chen et al 2003). Change vector analysis in posterior-probability space (CVAPS) (Chen et al 2011) relaxes the strict requirement of radiometric consistency in remotely sensed data while this requirement is a bottleneck of CVA. In CVAPS approach, the posterior probability is implemented by maximum likelihood classifier (MLC) (Castellana et al 2007). Assuming that the posterior probability vectors of one pixel in time 1 and time 2 are ${ }^{\prime} \mathrm{P}_{\mathrm{a}}^{\prime}$ and ${ }^{\prime} \mathrm{P}_{\mathrm{b}}^{\prime}$, respectively. The change vector in a posterior probability space ${ }^{\prime} \Delta \mathrm{P}_{\mathrm{ab}}^{\prime}$ can be defined as

$$
\Delta \mathrm{P}_{\mathrm{ab}}=\mathrm{P}_{\mathrm{b}}-\mathrm{P}_{\mathrm{a}} .
$$

CVAPS technique follows the semiautomatic DFPS (Chen et al 2003) approach for the selection of threshold value. In CVAPS algorithm (figure 3c), direction of the change vector in a posterior probability space is determined by applying supervised classification. In figure 9, the binary

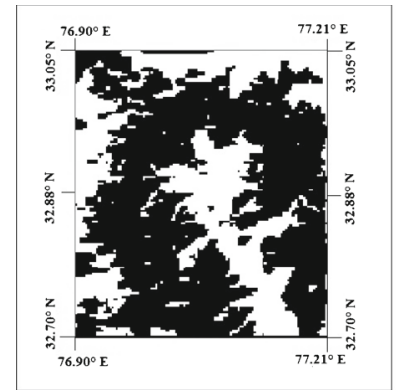

(a)

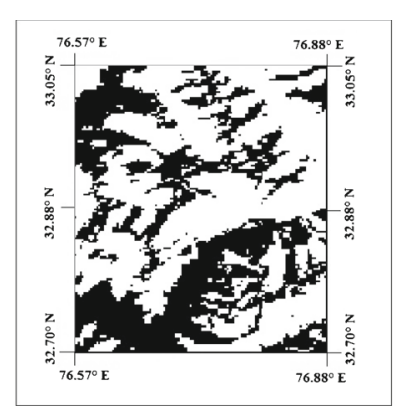

(b)

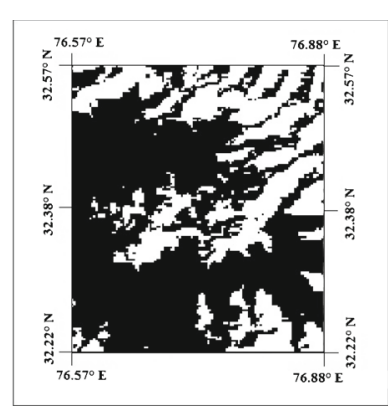

(c)

Figure 7. Binary imageries generated using ICVA: (a) Dataset 1, (b) Dataset 2 and, (c) Dataset 3. 


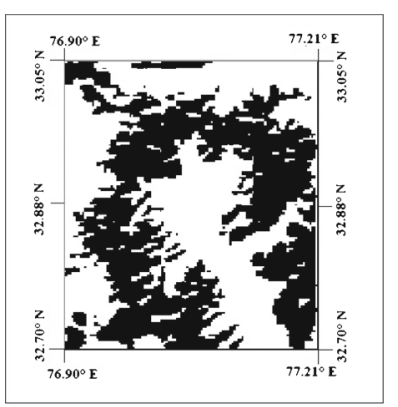

(a)

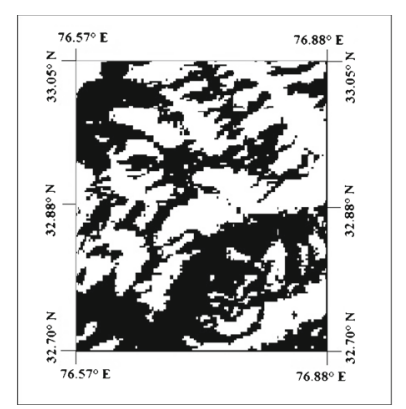

(b)

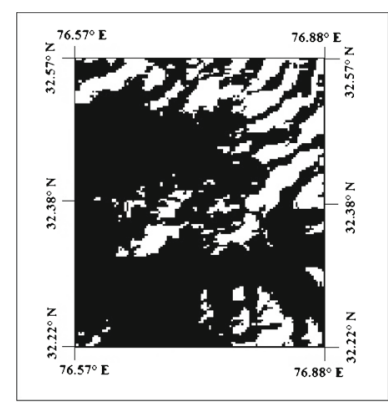

(c)

Figure 8. Binary imageries generated using MCVA: (a) Dataset 1, (b) Dataset 2 and, (c) Dataset 3.

image generated through CVAPS for three different data sets represented the 'change' pixels in white colour and 'no-change' pixels in black colour.

\subsection{Other integrated CVA techniques}

3.5a Improved traditional CVA using cross-correlogram spectral matching (CCSM) (Chunyang et al 2013): Cross-correlogram spectral matching (CCSM) technique has been proposed to overcome the difficulties of traditional change vector analysis (TCVA). The basic concept of CCSM is to recognize and exclude areas with no land-cover modification (no changes) from the total changes detected by it. CCSM technique tells the degree of shape similarity between vegetation index profiles to detect land-cover conversion.

3.5b CVA using enhanced PCA and inverse triangular function (Baisantry et al 2012): Another improvement in threshold value selection has been proposed by integrating principal component analysis (PCA) and inverse triangular (IT) function in CVA. In this algorithm (figure 3d), Kauth-Thomas tasseled cap transformation has been used to extract greennessbrightness coefficients.

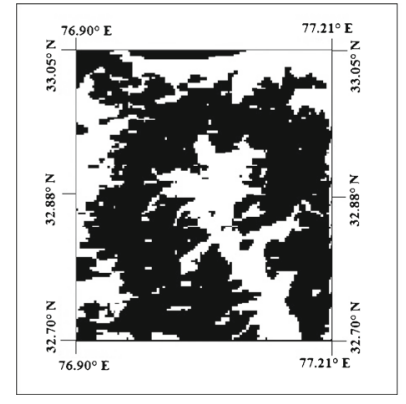

(a)

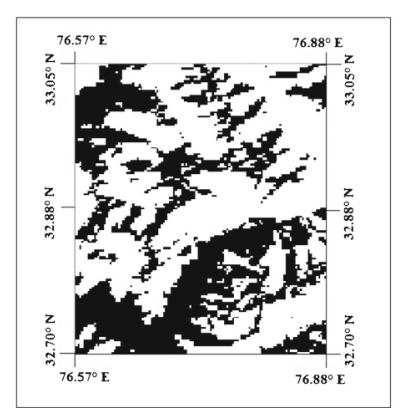

(b)

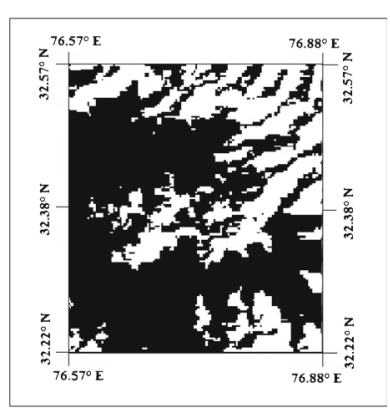

(c)

Figure 9. Binary imageries generated using CVAPS: (a) Dataset 1, (b) Dataset 2 and, (c) Dataset 3. 
3.5c Change vector analysis using distance and similarity measures (Osmar et al 2011): In this technique, spectral angle mapper (SAM) and spectral correlation mapper (SCM) are used to compute spectral change direction. The information is processed in one band only in which the scale value represents degree of change and insensitivity to illumination variation.

3.5d Median change vector analysis (Varshney et al 2012): In this algorithm, enhanced 2ndimensional feature space, integrates the change vector and median vector in direction cosine. This execution gives more accurate results than ICVA proposed by Chen Jin et al (2003).

3.5e CVA using tasselled cap transformation (Rene \& Barbara 2008): In this technique, dissimilarities in the time-trajectory of the Tasseled Cap greenness and brightness were computed and then applied to change vector analysis. It also reduced the multi-dimensional bands and at the same time emphasized change categories of the land cover.

\section{Results and discussion}

In order to evaluate each CVA technique, accuracy assessment has been computed using three different MODIS satellite data sets for decision making process. The important accuracy assessment terms involve overall accuracy, commission errors and Kappa coefficient (Gautam \& Chennaiah 1985; Congalton 1991; Congalton \& Green 1998; Congalton \& Plourde 2002; Congalton et al 1983). With experimental outcomes, it is observed that CVA technique achieved 0.40 kappa coefficient and 70\% accuracy assessment for dataset 1 (table 4), 0.48 kappa coefficient and 74\% accuracy assessment for dataset 2 (table 5) and 0.48 kappa coefficient and 74\% accuracy assessment for dataset 3 (table 6). MCVA technique has achieved 0.64 kappa coefficient and 82\% accuracy assessment for dataset 1 (table 7), 0.64 kappa coefficient and $82 \%$ accuracy assessment for dataset 2 (table 8) and 0.64 kappa coefficient and 82\% accuracy assessment for dataset 3 (table 9). ICVA technique has achieved 0.68 kappa coefficient and $84 \%$ accuracy assessment for dataset 1 (table 10), 0.72 kappa coefficient and $86 \%$ accuracy assessment for dataset 2 (table 11) and 0.72 kappa coefficient and $86 \%$ accuracy assessment for dataset 3 (table 12). CVAPS technique has achieved 0.84 kappa coefficient and 92\% accuracy assessment for dataset 1 (table 13),

Table 4. Accuracy assessment of CVA technique using 50 samples for dataset 1.

\begin{tabular}{llcccc}
\hline Reference change & \multicolumn{1}{c}{$\begin{array}{c}\text { Un-change } \\
\text { pixels }\end{array}$} & $\begin{array}{c}\text { Change } \\
\text { pixels }\end{array}$ & Sum & $\begin{array}{c}\text { Commission } \\
\text { error }\end{array}$ \\
\hline $\begin{array}{l}\text { Classified } \\
\text { change }\end{array}$ & $\begin{array}{l}\text { Un-change } \\
\text { pixels }\end{array}$ & 18 & 7 & 25 & $28 \%$ \\
$\begin{array}{l}\text { Change } \\
\text { pixels }\end{array}$ & 8 & 17 & 25 & $32 \%$ \\
& $\begin{array}{l}\text { Sum } \\
\text { Commission } \\
\text { error }\end{array}$ & $30.76 \%$ & $29.16 \%$ & 50 & \\
& & & & &
\end{tabular}

Accuracy assessment $=70 \%$

Kappa coefficient $=0.40$ 
Table 5. Accuracy assessment of CVA technique using 50 samples for dataset 2.

\begin{tabular}{llcccc}
\hline Reference change & $\begin{array}{c}\text { Un-change } \\
\text { pixels }\end{array}$ & $\begin{array}{c}\text { Change } \\
\text { pixels }\end{array}$ & Sum & $\begin{array}{c}\text { Commission } \\
\text { error }\end{array}$ \\
\hline $\begin{array}{l}\text { Classified } \\
\text { change }\end{array}$ & $\begin{array}{l}\text { Un-change } \\
\text { pixels } \\
\text { Change }\end{array}$ & 21 & 4 & 25 & $16 \%$ \\
& $\begin{array}{l}\text { pixels } \\
\text { Sum } \\
\text { Commission } \\
\text { error }\end{array}$ & $30 \%$ & 16 & 25 & $36 \%$ \\
& & $30 \%$ & 20 & 50 & \\
& & & & &
\end{tabular}

Accuracy assessment $=74 \%$

Kappa coefficient $=0.48$

Table 6. Accuracy assessment of CVA technique using 50 samples for dataset 3.

\begin{tabular}{llcccc}
\hline Reference change & $\begin{array}{c}\text { Un-change } \\
\text { pixels }\end{array}$ & $\begin{array}{c}\text { Change } \\
\text { pixels }\end{array}$ & Sum & $\begin{array}{c}\text { Commission } \\
\text { error }\end{array}$ \\
\hline $\begin{array}{l}\text { Classified } \\
\text { change }\end{array}$ & $\begin{array}{l}\text { Un-change } \\
\text { pixels }\end{array}$ & 21 & 4 & 25 & $16 \%$ \\
& $\begin{array}{l}\text { Change } \\
\text { pixels }\end{array}$ & 9 & 16 & 25 & $36 \%$ \\
& $\begin{array}{l}\text { Sum } \\
\text { Commission } \\
\text { error }\end{array}$ & $30 \%$ & 20 & 50 & \\
& & & $20 \%$ & &
\end{tabular}

Accuracy assessment $=74 \%$

Kappa coefficient $=0.48$

Table 7. Accuracy assessment of MCVA technique using 50 samples for dataset 1 .

\begin{tabular}{llcccc}
\hline Reference change & & $\begin{array}{c}\text { Un-change } \\
\text { pixels }\end{array}$ & $\begin{array}{c}\text { Change } \\
\text { pixels }\end{array}$ & Sum & $\begin{array}{c}\text { Commission } \\
\text { error }\end{array}$ \\
\hline $\begin{array}{l}\text { Classified } \\
\text { change }\end{array}$ & $\begin{array}{l}\text { Un-change } \\
\text { pixels } \\
\text { Change } \\
\text { pixels }\end{array}$ & 21 & 4 & 25 & $16 \%$ \\
& $\begin{array}{l}\text { Sum } \\
\text { Commission } \\
\text { error }\end{array}$ & $19.23 \%$ & $16.66 \%$ & 50 & $20 \%$ \\
& & & & & \\
Accuracy assessment $=82 \%$ & & & & \\
Kappa coefficient & $=0.64$ & & & & \\
\hline
\end{tabular}


Table 8. Accuracy assessment of MCVA technique using 50 samples for dataset 2.

\begin{tabular}{llcccc}
\hline Reference change & $\begin{array}{c}\text { Un-change } \\
\text { pixels }\end{array}$ & $\begin{array}{c}\text { Change } \\
\text { pixels }\end{array}$ & Sum & $\begin{array}{c}\text { Commission } \\
\text { error }\end{array}$ \\
\hline $\begin{array}{l}\text { Classified } \\
\text { change }\end{array}$ & $\begin{array}{l}\text { Un-change } \\
\text { pixels } \\
\text { Change } \\
\text { pixels }\end{array}$ & 19 & 6 & 25 & $24 \%$ \\
& $\begin{array}{l}\text { Sum } \\
\text { Commission } \\
\text { error }\end{array}$ & $13.63 \%$ & $21.42 \%$ & & \\
& & & & & \\
& & & & & \\
Accuracy assessment $=82 \%$ & & & & \\
Kappa coefficient & $=0.64$ & & & & \\
\hline
\end{tabular}

Table 9. Accuracy assessment of MCVA technique using 50 samples for dataset 3 .

\begin{tabular}{llcccc}
\hline Reference change & \multicolumn{1}{c}{$\begin{array}{c}\text { Un-change } \\
\text { pixels }\end{array}$} & $\begin{array}{c}\text { Change } \\
\text { pixels }\end{array}$ & Sum & $\begin{array}{c}\text { Commission } \\
\text { error }\end{array}$ \\
\hline $\begin{array}{l}\text { Classified } \\
\text { change }\end{array}$ & $\begin{array}{l}\text { Un-change } \\
\text { pixels }\end{array}$ & 22 & 3 & 25 & $12 \%$ \\
& $\begin{array}{l}\text { Change } \\
\text { pixels }\end{array}$ & 6 & 19 & 25 & $24 \%$ \\
& $\begin{array}{l}\text { Sum } \\
\text { Commission } \\
\text { error }\end{array}$ & $21.42 \%$ & $13.63 \%$ & 50 & \\
& & & & &
\end{tabular}

Accuracy assessment $=82 \%$

Kappa coefficient $=0.64$

Table 10. Accuracy assessment of ICVA technique using 50 samples for dataset 1.

\begin{tabular}{llcccc}
\hline Reference change & $\begin{array}{c}\text { Un-change } \\
\text { pixels }\end{array}$ & $\begin{array}{c}\text { Change } \\
\text { pixels }\end{array}$ & Sum & $\begin{array}{c}\text { Commission } \\
\text { error }\end{array}$ \\
\hline $\begin{array}{l}\text { Classified } \\
\text { change }\end{array}$ & $\begin{array}{l}\text { Un-change } \\
\text { pixels }\end{array}$ & 22 & 3 & 25 & $12 \%$ \\
& $\begin{array}{l}\text { Change } \\
\text { pixels }\end{array}$ & 5 & 20 & 25 & $20 \%$ \\
& $\begin{array}{l}\text { Sum } \\
\text { Commission } \\
\text { error }\end{array}$ & $18.51 \%$ & $13.04 \%$ & 50 & \\
& & & & &
\end{tabular}

Accuracy assessment $=84 \%$

Kappa coefficient $=0.68$ 
Table 11. Accuracy assessment of ICVA technique using 50 samples for dataset 2.

\begin{tabular}{llcccc}
\hline Reference change & $\begin{array}{c}\text { Un-change } \\
\text { pixels }\end{array}$ & $\begin{array}{c}\text { Change } \\
\text { pixels }\end{array}$ & Sum & $\begin{array}{c}\text { Commission } \\
\text { error }\end{array}$ \\
\hline $\begin{array}{l}\text { Classified } \\
\text { change }\end{array}$ & $\begin{array}{l}\text { Un-change } \\
\text { pixels } \\
\text { Change } \\
\text { pixels }\end{array}$ & 21 & 4 & 25 & $16 \%$ \\
& $\begin{array}{l}\text { Sum } \\
\text { Commission } \\
\text { error }\end{array}$ & 3 & 22 & 25 & $12 \%$ \\
& $12.50 \%$ & $15.38 \%$ & 50 & \\
Accuracy assessment $=86 \%$ & & & & \\
Kappa coefficient & $=0.72$ & & & & \\
\hline
\end{tabular}

Table 12. Accuracy assessment of ICVA technique using 50 samples for dataset 3 .

\begin{tabular}{llcccc}
\hline Reference change & \multicolumn{1}{c}{$\begin{array}{c}\text { Un-change } \\
\text { pixels }\end{array}$} & $\begin{array}{c}\text { Change } \\
\text { pixels }\end{array}$ & Sum & $\begin{array}{c}\text { Commission } \\
\text { error }\end{array}$ \\
\hline $\begin{array}{l}\text { Classified } \\
\text { change }\end{array}$ & $\begin{array}{l}\text { Un-change } \\
\text { pixels }\end{array}$ & 22 & 3 & 25 & $12 \%$ \\
& $\begin{array}{l}\text { Change } \\
\text { pixels }\end{array}$ & 4 & 21 & 25 & $16 \%$ \\
& $\begin{array}{l}\text { Sum } \\
\text { Commission } \\
\text { error }\end{array}$ & $15.38 \%$ & $12.5 \%$ & 50 & \\
& & & & &
\end{tabular}

Accuracy assessment $=86 \%$

Kappa coefficient $=0.72$

Table 13. Accuracy assessment of CVAPS technique using 50 samples for dataset 1 .

\begin{tabular}{llcccc}
\hline Reference change & $\begin{array}{c}\text { Un-change } \\
\text { pixels }\end{array}$ & $\begin{array}{c}\text { Change } \\
\text { pixels }\end{array}$ & Sum & $\begin{array}{c}\text { Commission } \\
\text { error }\end{array}$ \\
\hline $\begin{array}{l}\text { Classified } \\
\text { change }\end{array}$ & $\begin{array}{l}\text { Un-change } \\
\text { pixels }\end{array}$ & 23 & 2 & 25 & $8 \%$ \\
& $\begin{array}{l}\text { Change } \\
\text { pixels }\end{array}$ & 2 & 23 & 25 & $8 \%$ \\
& $\begin{array}{l}\text { Sum } \\
\text { Commission }\end{array}$ & 25 & 25 & 50 & \\
& error & & $8 \%$ & &
\end{tabular}

Accuracy assessment $=92 \%$

Kappa coefficient $=0.84$ 
Table 14. Accuracy assessment of CVAPS technique using 50 samples for dataset 2.

\begin{tabular}{llcccc}
\hline Reference change & \multicolumn{1}{c}{$\begin{array}{c}\text { Un-change } \\
\text { pixels }\end{array}$} & $\begin{array}{c}\text { Change } \\
\text { pixels }\end{array}$ & Sum & $\begin{array}{c}\text { Commission } \\
\text { error }\end{array}$ \\
\hline $\begin{array}{l}\text { Classified } \\
\text { change }\end{array}$ & $\begin{array}{l}\text { Un-change } \\
\text { pixels }\end{array}$ & 23 & 2 & 25 & $8 \%$ \\
& $\begin{array}{l}\text { Change } \\
\text { pixels }\end{array}$ & 2 & 23 & 25 & $8 \%$ \\
& $\begin{array}{l}\text { Sum } \\
\text { Commission }\end{array}$ & 25 & 25 & 50 & \\
& error & & $8 \%$ & &
\end{tabular}

Accuracy assessment $=92 \%$

Kappa coefficient $=0.84$

0.84 kappa coefficient and 92\% accuracy assessment for dataset 2 (table 14) and 0.84 kappa coefficient and 92\% accuracy assessment for dataset 3 (table 15).

It has been analysed that CVA analysis can be a useful tool for assessing continuous change. CVA technique was initially designed for interpretation of two spectral bands or dimensions and later extended to the unlimited number of bands using MCVA technique. ICVA presented first semi-automatic DFPS algorithm for threshold value determination, and change vector determination based on cosine functions in a multi-dimensional space. CVAPS eliminates the strict requirement of reliable image radiometry by incorporating the merits of post-classification comparison (PCC) into CVA. All CVA based change detection techniques are compared on the basis of their characteristics, advantages, disadvantages and their examples are given in table 16. The CVA technique provides number of features such as less sensitive to atmospheric effects, describes the output in terms of overall magnitude of change and direction of change, simultaneously processing of multiple bands, semi/automatic threshold finding process, etc. these factors make the perfect choice of CVA as change detection technique.

Table 15. Accuracy assessment of CVAPS technique using 50 samples for dataset 3 .

\begin{tabular}{llcccc}
\hline Reference change & $\begin{array}{c}\text { Un-change } \\
\text { pixels }\end{array}$ & $\begin{array}{c}\text { Change } \\
\text { pixels }\end{array}$ & Sum & $\begin{array}{c}\text { Commission } \\
\text { error }\end{array}$ \\
\hline $\begin{array}{l}\text { Classified } \\
\text { change }\end{array}$ & $\begin{array}{l}\text { Un-change } \\
\text { pixels }\end{array}$ & 24 & 1 & 25 & $4 \%$ \\
& $\begin{array}{l}\text { Change } \\
\text { pixels }\end{array}$ & 3 & 22 & 25 & $12 \%$ \\
& $\begin{array}{l}\text { Sum } \\
\text { Commission } \\
\text { error }\end{array}$ & $11.11 \%$ & $4.34 \%$ & 50 & \\
& & & & &
\end{tabular}

Accuracy assessment $=92 \%$

Kappa coefficient $=0.84$ 












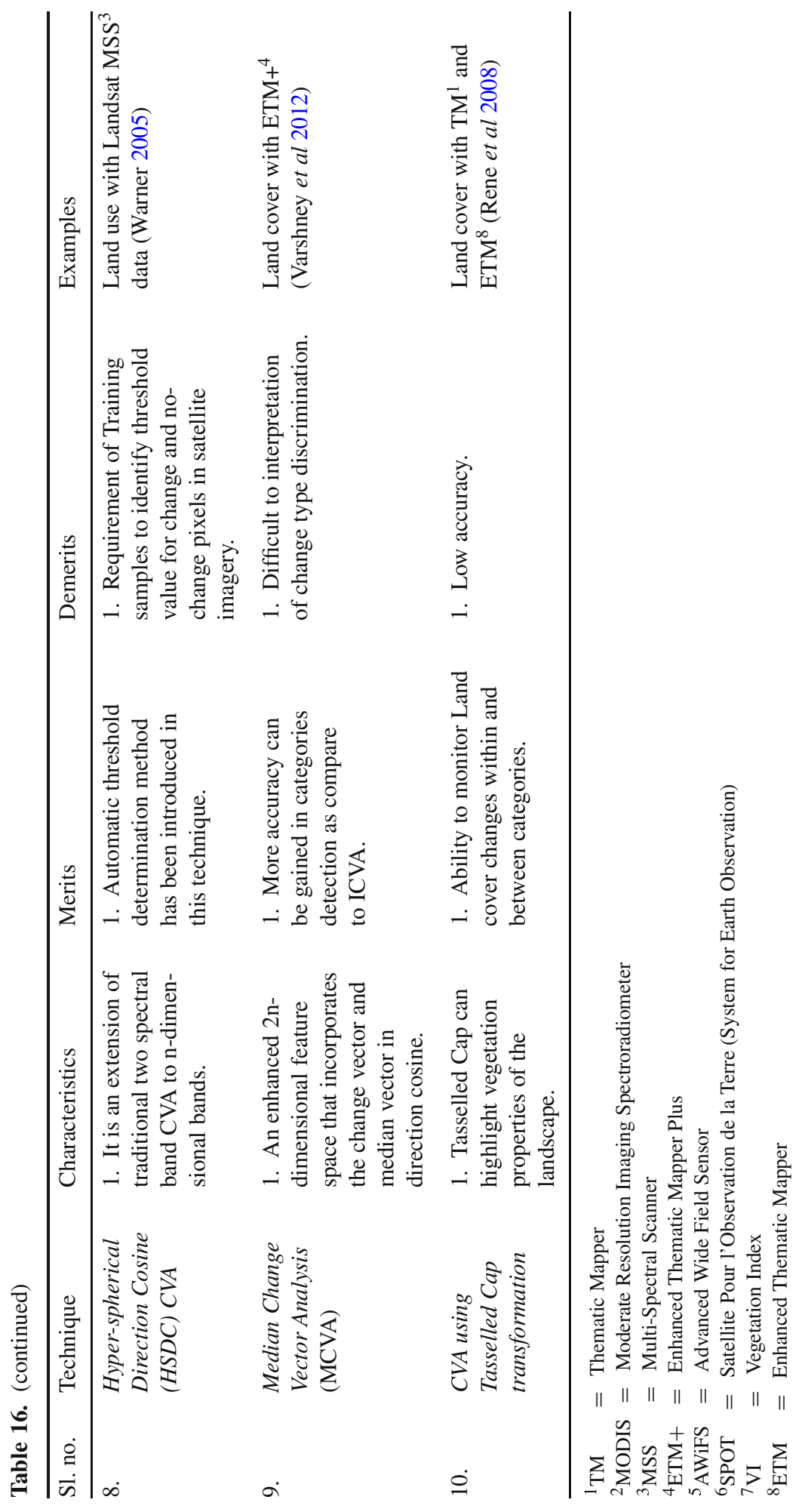




\section{Conclusion}

It has been concluded that CVA technique has achieved 70 to $74 \%$ overall accuracy assessment and MCVA technique has achieved $82 \%$ overall accuracy assessment. On the other hand, ICVA technique achieved $84 \%$ to $86 \%$ overall accuracy assessment and CVAPS technique achieved $92 \%$ overall accuracy assessment. The double-window flexible pace search (DFPS) technique plays a significant role in ICVA and CVAPS to detect more accurately the LULC changes. Whereas CVA and MCVA have achieved less accuracy because of empirical threshold determination techniques. It has been also noted that commission errors have also been improved in ICVA and CVAPS as compared to CVA and MCVA. Furthermore, this paper also has summarized the well-defined change vector analysis (CVA) based change detection techniques with their comparative analysis and has provided recommendations for algorithms designers to experiment CVA on global basis and discovering new techniques that efficiently use the diverse and complex remotely sensed data for flat as well as undulating surface.

\section{References}

Allen T R and Kupfer J A 2000 Alication of spherical statistics to change vector analysis of Landsat data: Southern Aalachian spruce-fir forests. Remote Sensing of Env. 74: 482-493

Baisantry M, Negi D S and Manocha O P 2012 Change vector analysis using enhanced PCA and Inverse triangular function-based thresholding. Defence Sci. J. 62(4): 236-242

Castellana L, Addabbo A D' and Pasquariello G 2007 A composed supervised/unsupervised approach to improve change detection from remote sensing. Pattern Recognition Lett. 28: 405-413

Chavez P S J 1984 Radiometric calibration of Landsat thematic layer multispectral images. Photogrammetric Eng. Remote Sensing 55(9): 1285-1294

Chavez P S 1996 Image-based atmospheric corrections-revisited and improved. Photogrammetric Eng. Remote Sensing 62: 1025-1036

Chen Jin, Chen Xuehong, Xihong Cui and Jun Chen 2011 Change Vector analysis in posterior probability space: A new method for land cover change detection. IEEE Geosci. and Remote Sensing Lett. 8(2): 317-321

Chen Jin, Peng Gong, Chunyang He, Pu Ruiliang and Peijun Shi 2003 Land-use/land-cover change detection using improved change-vector analysis. Photogrammetric Eng. and Remote Sensing 69(4): 369379

Chunyang He, Yuanyuan Zhao, Jie Tian, Peijun Shi and Qingxu Huang 2013 Improving change vector analysis by cross- orrelogram spectral matching for accurate detection of land-cover conversion. Int. J. Remote Sensing 34(4): 1127-1145

Civco D L, Hurd J D, Wilson E H, Song M and Zhang Z 2002 A comparison of land use and land cover change detection methods. American Congress on Surveying \& Mapping - American Society for Photogrammetry and Remote Sensing 2002 Annual Conference Proceedings

Collins J B and Woodcock C E 1994 Change detection using the Gramm-Schmidt transformation alied to maing forest mortality. Remote Sensing of Env. 50: 267-279

Congalton R G 1991 A review of assessing the accuracy of classifications of remotely sensed data. Remote Sensing of Environ. 37: 35-46

Congalton R G and Green K 1998 Assessing the accuracy of remotely sensed data: Principles and Practices F L Boca Raton (ed.) USA: CRC/Lewis Press 49-63

Congalton R G and Plourde L 2002 Quality assurance and accuracy assessment of information derived from remotely sensed data. Manual of Geospatial Sci. Technol. J Bossler (ed.) London: Taylor \& Francis 349-361

Congalton R G, Oderwald R G and Mead R A 1983 Assessing Landsat classification accuracy using discrete multivariate analysis statistical techniques. Photogrammetric Eng. and Remote Sensing 49: 1671-1678 
Ding Y, Elvidge C D and Ross S Lunetta 1998 Survey of multispectral methods for land cover change detection analysis. Remote Sensing Change Detection: Environmental Monitoring Methods and Applications, Ross S Lunetta and Christopher D Elvidge (eds) Sleeping Bear Press Inc. New York NY 21-39

Gautam N C and Chennaiah G C 1985 Land-use and land-cover maing and change detection in Tripura using satellite Landsat data. Int. J. Remote Sensing 6: 517-528

Gilabert M A, Conese C and Maselli F 1994 An atmospheric correction method for the automatic retrieval of surface reflectance from TM images. Int. J. Remote Sensing 15: 2065-2086

Hame T, Heiler I and Miguel-Ayanz J S 1998 An unsupervised change detection and recognition system for forestry. Int. J. Remote Sensing 19: 1079-1099

Hoffmann B 1975 about vectors Dover Publications Inc New York 134

Houhoulis P F and Michener W K 2000 Detecting wetland change: A rule-based aroach using NWI and SPOT-XS data. Photogrammetric Eng. and Remote Sensing 66: 205-211

Howarth P J and Wickware G M 1981 Procedures for change detection using Landsat digital data. Int. J. Remote Sensing 2: 277-291

Johnson R D and Kasischke E S 1998 Change vector analysis: A technique for the multispectral monitoring of land-cover and condition. Int. J. Remote Sensing 19: 411-26

Kasten F 1989 Table of solar altitudes for geographical effect on spectral response from nadir pointing sources. CRREL Spec. Rep. 57

Lambin E F and Strahler A H 1994 Change-vector analysis in multi-temporal space: a tool to detect and categorize land-cover change processes using high temporal-resolution satellite data. Remote Sensing of Env. 48: 231-44

Lu D, Mausel P, Brondizio E and Moran E 2003 Change detection techniques. Int. J. Remote Sensing 25: 2365-2407

Malila W 1980 Change vector analysis: An aroach for detecting forest changes with Landsat Proceedings of the 6th Annual Symposium on Machine Processing of Remotely Sensed Data West Lafayette IN USA Purdue University Press: West Lafayette IN USA 326-335

Markham B L and Barker J L 1987 Thematic Maer bandpass solar exo-atmospheric irradiances. Int. J. Remote Sensing 8: 517-523

Mcgovern E A, Holden N M, Ward S M and Collins J F 2002 The radiometric normalization of multitemporal Thematic Mapper imagery of the midlands of Ireland-a case study. Int. J. Remote Sensing 23: 751-766

Michalek J L, Wagner T W, Luczkovich J J and Stoffle R W 1993 Multispectral change vector analysis for monitoring coastal marine environments. Photogrammetric Eng. Remote Sensing 59: 381-384

Mishra V D, Sharma J K and Khanna R 2009a Review of topographic analysis techniques for the western Himalaya using AWiFS and MODIS satellite imagery. Annals of Glaciology 51(54): 1-8

Mishra V D, Sharma J K, Singh K K, Thakur N K and Kumar M 2009b Assessment of different topographic corrections in AWiFS satellite imagery of Himalaya terrain. J. Earth System Sci. 118(1): 11-26

Nackaerts K, Vaesen K, Muys B and Coin P 2005 Comparative performance of a modified change vector analysis in forest change detection. Int. J. Remote Sensing 26(5): 839-852

Nelson R F 1983 Detecting forest canopy change due to insect activity using Landsat MSS. Photogrammetric Eng. and Remote Sensing 49: 1303-1314

Osmar A, Renato C J, Guimarães F, Gillespie A R, Silva N C and Gomes Roberto A T 2011 A New approach to change vector analysis using distance and similarity measures. Remote Sensing 3: 24732493

Pandya M R, Singh R P, Murali K R, Babu P N, Kiran kumar A S and Dadhwal V K 2002 Band pass solar exo-atmospheric irradiance and Rayleigh optical thickness of sensors on board Indian remote sensing satellites-1B -1C -1D and P4. IEEE Trans. Geosci. Remote Sensing 40(3): 714-718

Rene Ngamabou Siwe and Barbara Koch 2008 Change vector analysis to categorise land cover change processes using the tasselled cap as biophysical indicator. Environmental Monitoring and Assessment 145: $227-235$ 
Sharma J K, Mishra V D and Khanna R 2013 Impact of Topography on Accuracy of Land Cover Spectral Change Vector Analysis Using AWiFS in Western Himalaya. J. the Indian Soc. Remote Sensing 41(2): 223-235

Silva P G, Santos J R, Shimabukuro Y E, Souza P E U and Graça P M L A 2003 Change vector analysis technique to monitor selective logging activities in Amazon. IEEE Geosci. Remote Sensing 4: 2580-2582

Singh A 1986 Change detection in the tropical forest environment of northeastern Indiausing Landsat. Remote Sensing and Tropical Land Management Eden M J and Parry J T (eds): New York: J Wiley 237-254

Singh A 1989 Digital change detection techniques using remotely sensed data. Int. J. Remote Sensing 10: 989-1003

Smits C Paul and Alessandro Annoni 2000 Toward specification driven change detection. IEEE Transactions on Geosci. Remote Sensing 38(3): 1484-1488

Sohl T L 1999 Change analysis in the United Arab Emirates: an investigation of techniques. Photogrammetric Eng. Remote Sensing 65(4): 475-484

Song C, Woodcock C E, Seto K C, Lenney M P and Macomber S A 2001 Classification and change detection using Landsat TM data: when and how to correct atmospheric effects. Remote Sensing Environ. 75(2): 230-244

Srinivasulu J and Kulkarni A V 2004 Estimation of spectral reflectance of snow from IRS-1D LISS-III sensor over the Himalayan terrain. Proc. Indian Acad. Sci. Earth Planet Sci. 113(1): 117-128

Stefan S and Itten K I 1997 A physically-based model to correct atmospheric and illumination effects in optical satellite data of rugged terrain. IEEE Transactions on Geosci. Remote Sensing 35: 708-717

Tokola T, Fman Lö S and Erkkila A 1999 Relative calibration of multi-temporal Landsat data for forest cover change detection. Remote Sensing of Env. 68: 1-11

Varshney A, Arora M K and Ghosh J K 2012 Median change vector analysis algorithm for land-use landcover change detection from remote-sensing data. Remote Sensing Lett. 3(7): 605-614

Van der Meer F 1989 Spectral mixture modelling and spectral stratigraphy in carbonate lithofacies maing. ISPRS J. Photogrammetric Remote Sensing 51(3): 150-162

Vermote E, Tanre D, Deuze J L, Herman M and Morcrette J J 1997 Second simulation of the satellite signal in the solar spectrum 6S: an overview. IEEE Transactions on Geosci. Remote sensing 35: 675-686

Warner T A 2005 Hyper spherical direction cosine change vector analysis. Int. J. Remote Sensing 26: 12011215

Weismiller R A, Kristof S Y, Scholz D K, Anuta P E and Momin S A 1977 Change detection in coastal zone environments. Photogrammetric Eng. Remote Sensing 43: 1533-1539

Yang X and Lo C P 2000 Relative radiometric normalization performance for change detection from multidate satellite images. Photogrammetric Eng. Remote Sensing 66: 967-980 